\title{
Inflorescence production in plants and in seed crops of $P o a$ pratensis L. and Festuca rubra L. as affected by juvenility of tillers and tiller density
}

\author{
W. J. M. Meijer
}

Research Station for Arable Farming and Field Production of Vegetables (PAGV), P.O. Box 430, 8200 AK Lelystad, Netherlands

Received 23 March 1984; accepted 25 April 1984

Key-words: grass seed, juvenile stage, sowing time, sowing rate, smooth-stalked meadow grass, Kentucky bluegrass, red fescue

\section{Summary}

When sown under a cover crop, the vegetative development of seed crops of smooth-stalked meadow grass and red fescue and, as a consequence, the production of inflorescences in the first year may vary considerably. In experiments with plants in pots the juvenility of tillers was studied and data were obtained on the juvenile stage. In field experiments, low inflorescence production in late-sown smooth-stalked meadow grass mainly resulted from too few tillers, whereas the tillers that emerged during late autumn and winter were very fertile. In late-sown red fescue crops, low inflorescence production mainly resulted from the low fertility of late emerging tillers. In field experiments on sowing rate density was found to have a considerable effect on the capacity of consecutive tillers to produce inflorescences. The mortality of later appearing generations of tillers increased rapidly. In conclusion, management methods to attain adequate crop development and to reduce density effects are discussed.

\section{Introduction}

In the Netherlands most smooth-stalked meadow grass (Poa pratensis L.) and red fescue (Festuca rubra L.) seed crops are sown under a winter wheat cover crop. In dense wheat crops the canopy closes early and growth of undersown grasses is often poor. After wheat harvest, such a disadvantaged grass seed crop will not attain the level of development desired: its tiller density is low and few large, vigorous tillers have developed. Growers have observed that such poor development of first-year grass seed crops often results in poor production of inflorescences, in continuing growth of vegetative tillers and in low seed yields. In contrast, in open cover crops grass growth is sometimes to vigorous and inflorescence production may be imped- 
ed by high tiller density. Another grass species important for Dutch seed producers is perennial ryegrass (Lolium perenne $\mathrm{L}$.). The production of inflorescences in perennial ryegrass is not so dependent on the vegetative crop development. When sown early, most ears are produced by early-formed autumn tillers. But with perennial ryegrass, late sowing and slight crop development in autumn do not necessarily limit seed yield, because a large number of ears can also be produced by late spring tillers (Hill \& Watkin, 1975; Kleinendorst, 1974; Foster, 1969; Ryle, 1964). Perennial species such as meadow fescue (Festuca pratensis Huds.), tall fescue ( $F$. arundinacea Schreb.), timothy (Phleum pratense L.) and cocksfoot (Dactylis glomerata L.) seem to be able to compensate fairly well by spring tillers (Lambert \& Jewis, 1970; Robson, 1968; Ryle, 1964; Langer \& Lambert, 1959). The capability of spring tillers to produce inflorescences is important for growers because grass species with this capability are easier to fit in crop rotations and total crop failure is rare.

Differences in the developmental behaviour of spring tillers among these species are only partly explained by the different durations of the periods of short days and low temperatures they require for floral induction. In perennial ryegrass the minimum duration of exposure to inductive conditions varies from several days to some months, dependent on cultivar or clone (Kleinendorst \& Brouwer, 1965; Evans, $1960 ;$ Fejer, 1960). In comparison, smooth-stalked meadow grass has been induced by a vernalization period of some six weeks (Evans, 1960; Heide, 1980). It is probably not the duration of the required floral induction period that mainly determines whether early spring tillers are able to produce inflorescences: the presence or absence of a juvenile stage could be more decisive. During a juvenile stage tillers are unable to respond to vernalizing conditions. In this way juvenility reinforces the perennial nature of several temperate grass species. It is unclear how such a juvenile stage should be characterized. Characteristics such as leaf number, tiller age and apex size have been suggested (Bean, 1970; Bommer, 1969; Calder, 1966; Cooper \& Calder, 1964). It seems probable that young tillers must at least have emerged from their parent leaf sheaths before induction can proceed. In perennial ryegrass, however, germinating seeds, young seedlings and also axillary buds can be vernalized (Cooper \& Calder, 1964; Bommer, 1961). As a result, in plants or crops of ryegrass, a multitude of inflorescences can be formed from tillers visible during vernalization (Kleinendorst, 1974). In the literature this absence of a juvenile stage is sometimes misinterpreted as translocation of floral induction. Although juvenility probably strongly affects the inflorescence production of crops of smooth-stalked meadow grass and red fescue, little information about this phenomenon is available. Elliott (1966) has demonstrated that young tillers and tiller initials in red fescue cannot be induced to flower. To date, no conclusive evidence has been presented for a juvenile stage in smooth-stalked meadow grass. But vernalization experiments on young plants have suggested that juvenility is present (Cooper \& Calder, 1964).

In widely spaced, young plants juvenility and age or size of tillers will be particularly important for reproductive development. In such plants there is little competition between tillers, and density will have no marked effect on inflorescence de- 
velopment. In dense seed crops, on the other hand, the number of adult and well developed vegetative tillers often far exceeds the ultimate number of inflorescences produced. In older stands crop density is probably the main factor determining numbers of fertile tillers. In first-year seed crops of smooth-stalked meadow grass and red fescue (depending on crop development) both juvenility of tillers and crop density may affect the production of inflorescences. In the present experiments with plants in pots and with field crops these aspects of inflorescence production were investigated.

Two experiments with plants of smooth-stalked meadow grass and red fescue in pots were set up to try to demonstrate the existence of a juvenile stage and to collect data on any such stage. The experiments were designed to make clear which tillers, emerging before or during vernalization, could be induced to flower. It was hoped that the results would be useful in determining the crop development in the field at the onset of winter that is desirable to ensure a high production of inflorescences.

In two series of field experiments, various crop types were obtained by sowing on different dates and using different sowing rates. By varying the sowing date tiller emergence can be manipulated to occur in summer or mainly in autumn. Crops resulting from different sowing dates will vary drastically in the number, size and age of tillers. In experiments with sowing rates, differences will arise mainly because of differences in the time that the crops close and because inter-plant competition controls whether tillering occurs earlier or later in autumn. The main objectives of these experiments were to investigate how seed crops should be managed to promote a high and stable inflorescence production, and to ascertain which crop structure results in few panicles and low seed yields.

\section{Materials and methods}

\section{Pot experiments}

Starting December 1976, 3 groups of 30 pots were sown at fortnightly intervals with smooth-stalked meadow grass (cv. Baron) in a greenhouse and thinned to 1 plant per pot after emergence.

The pots, which had a volume of 31 , were filled with a mixture of $2 / 3$ clay and $1 / 3$ peat. The plants were grown for 11 weeks at a day-night temperature regime of 18 $14{ }^{\circ} \mathrm{C}$ and a natural daylength ranging from 9 hours in January to 13 hours in April. Subsequently the plants were vernalized for 9 weeks under controlled conditions at $7{ }^{\circ} \mathrm{C}$ and a daylength of 8 hours. The light intensity in this period was circa $30 \mathrm{~W} \mathrm{~m}^{-2}$ at plant height $(400-700 \mathrm{~nm})$.

A week after emergence the main tillers of the 30 plants of one of these age groups ( 11 weeks old from emergence to the start of the vernalization treatment) were labelled with coloured plastic rings and every two to three weeks all newly emerged side tillers were ringed until approximately one week after the beginning of the vernalization treatment. An additional 20 plants from each sowing date were grown on and treated in the same way as the labelled plants, so they could be harvested at the beginning and end of the vernalization period and used to determine the mean weight of aerial tillers and the mean leaf area. Starting November 1977 
three groups of 30 plants of red fescue (cv. Koket) were sown at 3-week intervals and grown on for 19,16 and 13 weeks under identical environmental conditions as those for the smooth-stalked meadow grass. All these three age groups were vernalized for 15 weeks, beginning on the same date. Red fescue tillers abundantly and ringing is laborious, therefore 10 plants were selected at random from each of these age groups and were labelled in the same way as was done in smooth-stalked meadow grass. For each age group in this experiment 20 additional plants were also grown in order to obtain mean tiller weight and leaf area.

After vernalization all plants were placed outdoors in natural summer conditions. During that period daylength was approximately 16 hours. During July and August the lowest weekly minimum temperatures in both years were circa $12{ }^{\circ} \mathrm{C}$ and highest averaged maxima were circa $20^{\circ} \mathrm{C}$. During the whole growth period plants were adequately supplied with water and minerals.

At flowering the number of panicles per plant was counted. On the labelled plants, the number and the percentage of ringed tillers that produced inflorescences were determined.

\section{Field experiments}

In 1977, 1979 and 1980 smooth-stalked meadow grass (cv. Baron) and red fescue (cv. Koket) were sown without a cover crop on 5 different dates. In subsequent years these fields were harvested as first-year crops. Sowing dates were as close as possible to 22 May, 26 June, 18 July, 11 and 29 August, depending on weather and soil conditions. Sowing rates were $6 \mathrm{~kg} \mathrm{ha}^{-1}$ with smooth-stalked meadow grass and $8 \mathrm{~kg} \mathrm{ha}^{-1}$ with red fescue at a drill spacing of $25 \mathrm{~cm}$. At sowing crops were fertilized with $45 \mathrm{~kg} \mathrm{~N}$ ha-1. In February the spring dressing was applied: $90 \mathrm{~kg} \mathrm{~N} \mathrm{ha}^{-1}$ to smooth-stalked meadow grass and $70 \mathrm{~kg} \mathrm{~N}^{-1}$ to red fescue.

In 1978 and 1979 at the beginning of July the same cultivars were sown under flax at 4 different sowing rates in drills $25 \mathrm{~cm}$ apart: smooth-stalked meadow grass at 3 , 6,12 and $24 \mathrm{~kg} \mathrm{ha}^{-1}$ and red fescue at 4,8,16 and $32 \mathrm{~kg} \mathrm{ha}^{-1}$. Although these grasses are usually sown under a winter wheat cover crop, this was avoided in these trials in order to facilitate the counting and labelling of tillers. After the flax harvest all the crops were fertilized with $60 \mathrm{~kg} \mathrm{~N} \mathrm{ha}^{-1}$. The spring dressings were the same as in the sowing time trials.

All field trials were established in randomized blocks, gross plot size $40 \mathrm{~m}^{2}$, and carried out on a fertile marine clay-loam soil with a high water-holding capacity in the new Flevo Polders. During autumn tillers were counted approximately monthly in these experiments in order to monitor crop development. A fixed square of 0.25 $\mathrm{m}^{2}$ per plot was used to facilitate counting. In early December these squares were harvested and the mean dry weight of the tillers was determined. Seed production data were obtained by harvesting and threshing $25 \mathrm{~m}^{2}$ per plot. Before harvest the number of panicles was counted in a randomly chosen area of $0.25 \mathrm{~m}^{2}$.

In addition, in some of the above-mentioned field experiments vegetative and fertile tiller development was monitored by periodically labelling all the tillers that emerged from germination until March in a fixed square of $625 \mathrm{~cm}^{2}$ per plot. In order not to disturb tillering and heading in the fixed squares, from March until har- 
vest the total number of tillers in adjacent squares was counted. The laborious ringing of tillers was restricted to crops of both species sown on 3 of the sowing dates in the 1979 sowing time experiment and to the lowest and highest sowing rates of smooth stalked meadow grass in the 1980 sowing rate experiment. At seed harvest all the ringed inflorescences were classified according to time of tiller emergence, and the state at harvest of the labelled tillers was ascertained.

\section{Results and discussion}

\section{Juvenile stage of tillers}

In controlled environments almost all the plants could be induced to flower (Table 1). Some of the youngest plants remained fully vegetative. The vernalization treatment applied was chosen to satisfy the induction requirements of both species; these requirements were obtained from the literature. In smooth-stalked meadow grass induction has been found to be completed after a 6-week period of induction (Heide, 1980; Evans, 1960). Red fescue has been found to require and induction period of 12 to 15 weeks under field conditions (Murray et al., 1973; Cooper \& Calder, 1964). In some experiments under controlled conditions red fescue plants could not be induced for more than $20 \%$ (Bean, 1970; Elliott, 1966). It may be, as suggested by Cooper \& Calder (1964), that the extreme conditions sometimes found to be necessary to induce flowering were required because the plants or tillers had not passed the juvenile stage. Another explanation for the apparently extreme inductive requirements could be that under field conditions, the temperature for part of the period is below or above the assumed vernalizing range of $0-10{ }^{\circ} \mathrm{C}$ (Canode \& Perkins, 1977; Bean, 1970).

In our experiments devernalization could also have occurred after the plants were abruptly removed from the controlled inductive environment to the long days and high temperatures of July and August (Elliot, 1966; Evans, 1960). Vernalization operates on the tillers and this induction to floral development is not translocated from one tiller to another (Lindsey \& Peterson, 1964; Kleinendorst, 1974);

Table 1. Tiller growth of plants in the pot experiments and flowering after a vernalization treatment of 9 weeks (smooth stalked meadow grass) and 15 weeks (red fescue).

\begin{tabular}{|c|c|c|c|c|c|c|c|}
\hline & \multicolumn{4}{|c|}{ At beginning of vernalization treatment } & \multirow{2}{*}{$\begin{array}{l}\text { Flowering } \\
\text { plants }(\%)\end{array}$} & \multirow{2}{*}{$\begin{array}{l}\text { Panicles } \\
\text { per } \\
\text { plant }\end{array}$} & \multirow{2}{*}{$\begin{array}{l}\text { Panicles as } \\
\% \text { of initia } \\
\text { tillers }\end{array}$} \\
\hline & $\begin{array}{l}\text { plant } \\
\text { age, } \\
\text { weeks }\end{array}$ & $\begin{array}{l}\overline{\text { tillers }} \\
\text { per } \\
\text { plant }\end{array}$ & $\begin{array}{l}\text { weight, } \\
\text { mg per } \\
\text { tiller }\end{array}$ & $\begin{array}{l}\text { leaf area, } \\
\mathrm{cm}^{2} \text { per } \\
\text { tiller }\end{array}$ & & & \\
\hline $\begin{array}{l}\text { Poa pratensis } \\
(1977)\end{array}$ & $\begin{array}{r}9 \\
11 \\
13\end{array}$ & $\begin{array}{l}14 \\
33 \\
63\end{array}$ & $\begin{array}{r}7 \\
21 \\
33\end{array}$ & $\begin{array}{l}3.1 \\
3.5 \\
3.3\end{array}$ & $\begin{array}{r}90 \\
100 \\
100\end{array}$ & $\begin{array}{r}6 \\
16 \\
22\end{array}$ & $\begin{array}{l}43 \\
48 \\
35\end{array}$ \\
\hline $\begin{array}{l}\text { Festuca rubra } \\
(1978)\end{array}$ & $\begin{array}{l}13 \\
16 \\
19\end{array}$ & $\begin{array}{l}127 \\
220 \\
279\end{array}$ & $\begin{array}{r}9 \\
12 \\
13\end{array}$ & $\begin{array}{l}0.9 \\
1.1 \\
1.0\end{array}$ & $\begin{array}{r}90 \\
93 \\
100\end{array}$ & $\begin{array}{l}29 \\
49 \\
55\end{array}$ & $\begin{array}{l}23 \\
22 \\
20\end{array}$ \\
\hline
\end{tabular}




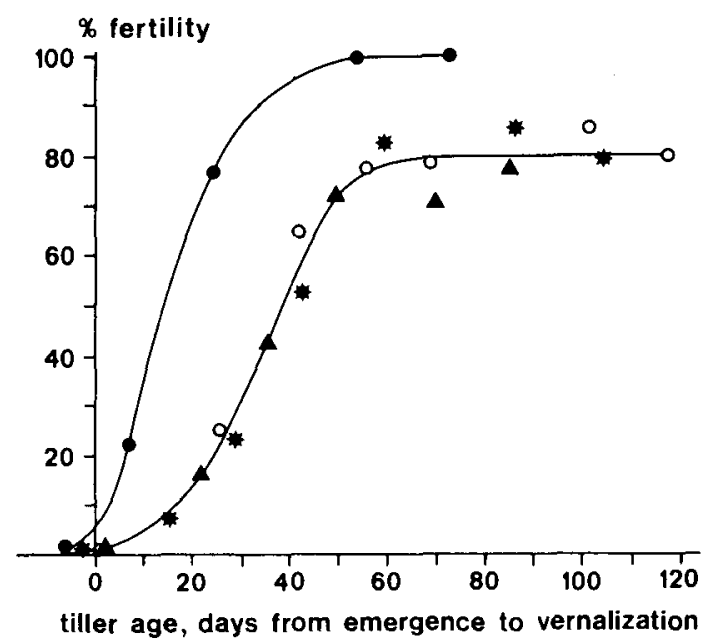

Fig. 1. Percentage fertility of consecutive appearing tillers from seedling emergence until beginning of the vernalization treatment at a plant age of 11 weeks in Poa pratensis (๑) and $13(\mathbf{\Delta}), 16(\star), 18(0)$ weeks in Festuca rubra.

therefore it is obvious that devernalization will also occur at tiller level. Of all the tillers in the present experiments that emerged before the vernalization treatments, on average, $42 \%$ of those of the smooth-stalked meadow grass and $22 \%$ of those of red fescue produced inflorescences (Table 1). All the tillers that remained vegetative had experienced the full induction period. Obviously these tillers were unable to respond to induction during the entire period or part of the period. In these experiments it is impossible to distinguish between incomplete induction and devernalization. Fig. 1 shows that in both species the tillers arising closer to the vernalization treatment produced fewer inflorescences. In smooth-stalked meadow grass less than $1 \%$ of all panicles were produced by tillers that emerged after the last labelling date at the beginning of the vernalization treatment; in red fescue the corresponding figure was zero. Obviously young tillers and tiller initials in these grass species cannot readily be induced: this demonstrates the presence of a juvenile stage.

In smooth-stalked meadow grass all the main tillers and all the first-emerged side tillers produced panicles. In red fescue approximately $80 \%$ of the older tillers in each of the plant age groups produced inflorescences. This difference in developmental behaviour may be related to the strong tillering tendency of this red fescue cultivar, which is bred for amenity use. Abundant tillering could reduce panicle production in two ways: directly, because these high tiller numbers cause mutual shading and possibly decrease assimilate availability per tiller (Ong, 1978: Spiertz \& Ellen, 1972; Ryle, 1967), and indirectly, because this high tillering continues during and after induction to flowering. Until these young tillers have rooted, their assimilate requirements are partly met by the main shoots and consequently the availability of assimilates for the older tillers is reduced (Clemence, 1982; Colvill \& Marshall, 1981; Ryle, 1970). Inflorescence production could fall if the reduced availability of assimilates limits floral induction or if stem growth and inflorescence growth are hampered. In dense crops the latter is probable, because often many 
more tillers become reproductive than are capable of attaining the flowering stage. Such non-flowering reproductive tillers have to die. But in these pot experiments almost all the tillers survived until harvest. This suggests that to a certain extent floral induction is affected by assimilate availability during or immediately after vernalization.

The results of these two experiments under almost identical environments suggest that in smooth-stalked meadow grass the juvenile stage is shorter than in red fescue, although a straight comparison cannot be made. The duration of the juvenile stage can be characterized as the tiller age (from emergence to the beginning of vernalization) at which $50 \%$ of maximum flowering is attained. As Fig. 1 shows, this results in smooth-stalked meadow grass having a juvenile stage of approximately 2 weeks, and red fescue having one of approximately 5 weeks.

In field crops with these densely tillering grasses it is difficult to distinguish between younger and older, juvenile and mature tillers. Some weeks after their appearance young tillers have developed approximately 3 leaves, as have most older tillers. Green leaf area per tiller is broadly the same thereafter. Therefore tiller weight may be a better criterion for differentiation between tillers (Table 1).

\section{Inflorescence production in sowing time experiments}

In first-year crops both the juvenility of tillers and tiller density could influence reproductive development and inflorescence production. Juvenility will probably be more important in crops that are weakly developed or are young at the beginning of the natural vernalization period. In older, vigorously developed crops, density effects could be more important. In three field experiments inflorescence production was studied in crops whose structure differed as a result of being sown on 5 different dates. In Table 2 the results of these experiments are summarized.

By the beginning of December the crops that had been sown in May, June or July had many tillers. In spring these red fescue and smooth-stalked meadow grass crops produced many panicles. Sowing in August resulted in substantially fewer tillers being present at the onset of winter, and in considerably fewer panicles.

The maximum number of vegetative tillers in red fescue was not attained in the earliest-sown crop. The early sown crops mainly grew at high temperatures and long days. The May sowing in particular gave rise to bigger tillers with long leaves. These crops closed early: this slowed down tillering. Later-sown crops mainly grew from September onwards (Fig. 2). Only when numerous did these smaller autumn tillers cause considerable mutual shading, which reduced tillering. Therefore the largest numbers of tillers in red fescue were attained in the June and July sowings. Smooth-stalked meadow grass tillers less abundantly and, after producing some side tillers, also produces rhizomes. Therefore in these crops the tiller density was less and autumn tillering was not markedly affected.

In these experiments, the smooth-stalked meadow grass crop sown at the end of August produced, on average, approximately half the number of panicles and seed yield of the crop sown on the earliest dates (Table 2). For red fescue the corresponding proportion was approximately one-third. Obviously in these crops seed yield depended mainly on number of panicles and less on number of seeds per inflo-

Neth. J. agric. Sci. 32 (1984) 
W. J. M. MEIJER

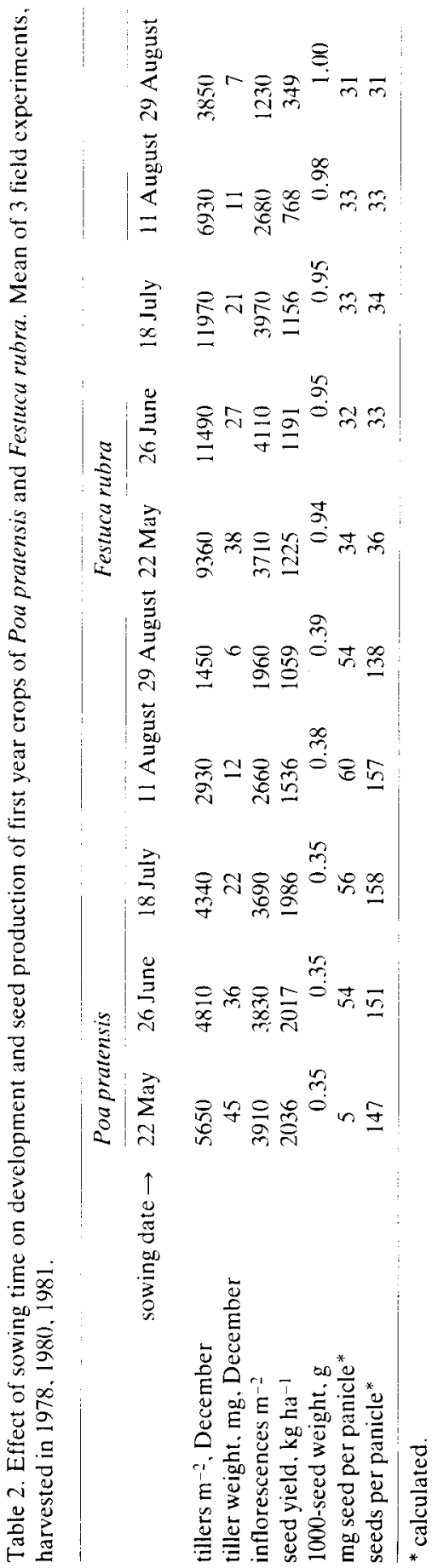


22 May
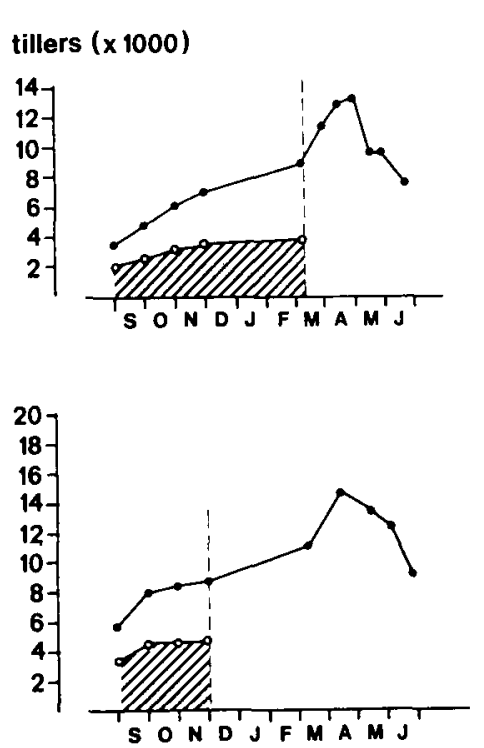

18 July

\section{Poa pratensis}
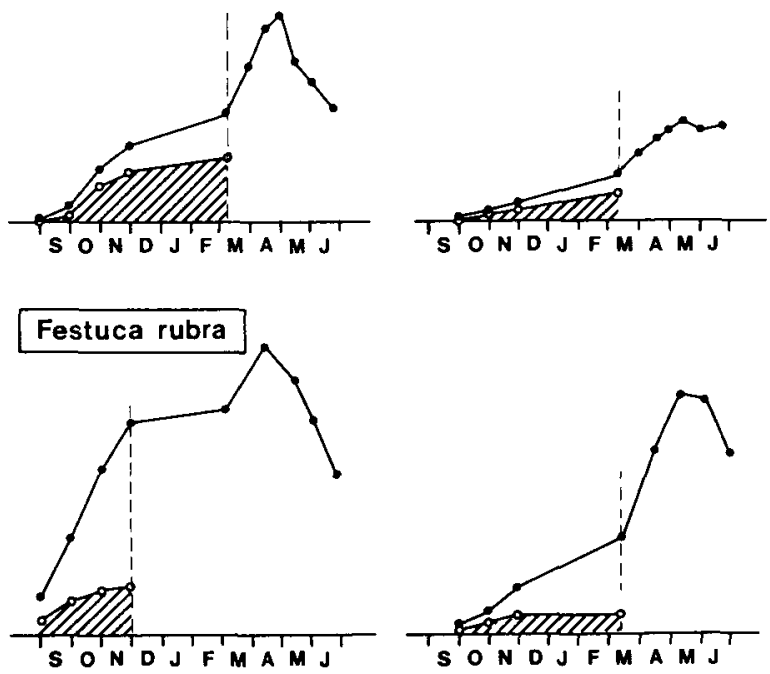

29 August

Fig. 2. Total number of tillers per $\mathrm{m}^{2}$ during the first growing season. The hatched area shows the time of origin and the numbers of the inflorescence-producing tillers; 3 sowing dates, field experiment $1979 / 80$.

rescence or on seed weight. In order to improve the interpretation of the above results and to obtain information on tiller development in different structured crops, the tillers of the crops sown in 1979 were labelled: tillers of crops sown on 3 of the sowing dates were ringed on 5 dates from the beginning of September to March. Absolute numbers of tillers per $\mathrm{m}^{2}$ are given in Fig. 2. The percentage of fertility of the tillers emerged in consecutive periods and the contribution from different periods to the total panicle production are given in Tables 3 and 4 . In both species the tillers that appeared earliest showed the highest capacity for inflorescence production and in later-formed tillers the percentage fertility progressively decreased. The fertility of tillers that emerged late in autumn was particularly low in red fescue. Tillers that had emerged after the beginning of December produced scarcely any panicles, whereas in smooth stalked meadow grass up to $70 \%$ of the tillers that emerged during winter still produced panicles.

In both species the effect of crop density on the fertility of tillers was striking. In each of the generations of tillers the highest percentage fertility was recorded in the latest sown crops, in which until heading, low numbers of small tillers established an open crop structure (Table 3). Even in their first year, the fertility of red fescue and smooth-stalked meadow grass crops is already substantially hampered by higher tiller densities.

The capacity of late winter and spring tillers to head will be most apparent in late sown or late planted crops. In such perennial ryegrass and Italian ryegrass crops a 
Table 3. Inflorescence production of the tillers that emerged from germination until March from crops sown on three sowing dates (field experiment 1979/80).

\begin{tabular}{|c|c|c|c|c|c|c|c|}
\hline \multirow[t]{2}{*}{ Sowing date } & & \multicolumn{5}{|c|}{ Fertility $(\%)$ of tillers emerged in consecutive periods } & \multirow{2}{*}{$\begin{array}{l}\text { Total number of } \\
\text { tillers from } \\
\text { sowing to March }\end{array}$} \\
\hline & & $\begin{array}{l}\text { sowing to } \\
\text { August }\end{array}$ & September & October & November & $\begin{array}{l}\text { Dec. to } \\
\text { March }\end{array}$ & \\
\hline \multirow[t]{3}{*}{ Poa pratensis, } & 22 May & 54 & 57 & 49 & 37 & 15 & 8750 \\
\hline & 18 July & 71 & 82 & 66 & 60 & 42 & 7150 \\
\hline & 29 August & - & 100 & 81 & 71 & 70 & 2630 \\
\hline \multirow[t]{3}{*}{ Festuca rubra, } & 22 May & 59 & 34 & 26 & 7 & 0 & 11100 \\
\hline & 18 July & 41 & 33 & 14 & 10 & 0 & 15210 \\
\hline & 29 August & - & 63 & 51 & 21 & 5 & 6370 \\
\hline
\end{tabular}

high proportion of spring tillers can become fertile and this generation of spring tillers can make a major contribution to total ear production (Hill \& Watkin, 1975; Foster, 1969; Wilson, 1959). Of the grass species of temperate climates, red fescue seems to be the other extreme: tillers that appeared after the beginning of December produced scarcely any panicles. The fertility of late tillers of smooth-stalked meadow grass is more comparable with that of species with an intermediate pattern, such as meadow fescue, tall fescue and cocksfoot (Hill \& Watkin, 1975; Robson, 1968; Langer \& Lambert, 1959; Wilson, 1959). The low production of inflorescences in late sowings of smooth-stalked meadow grass in our field trials, was mainly caused by the low numbers of vegetative tillers produced before early spring. The fertility of the late tillers was high (Table 3). In the late-sown fescue crops the opposite was true: the number of tillers that had emerged at the onset of winter may have been adequate but their fertility was low. This difference between the species in the fertility of late autumn and winter tillers appears to result from the greater duration of both the juvenile and induction stages of red fescue. Panicle production in red fescue is almost completely dependent on early tiller growth (Table 4). In smoothstalked meadow grass tillers appearing in late autumn and winter can, to a limited

Table 4. The contribution of tillers from different emergence periods to the total population of panicles in crops sown on three dates (field experiment 1979/80).

\begin{tabular}{|c|c|c|c|c|c|c|c|}
\hline \multirow[t]{2}{*}{ Sowing date } & & \multicolumn{4}{|c|}{ Contribution $(\%)$} & \multirow[b]{2}{*}{$\begin{array}{l}\text { Dec. to } \\
\text { March }\end{array}$} & \multirow{2}{*}{$\begin{array}{l}\text { Total number of } \\
\text { inflorescences } \\
\mathrm{m}^{-2}\end{array}$} \\
\hline & & $\begin{array}{l}\text { sowing to } \\
\text { August }\end{array}$ & September & October & November & & \\
\hline \multirow[t]{3}{*}{ Poa pratensis, } & $22 \mathrm{May}$ & 52 & 16 & 17 & 9 & 7 & 3850 \\
\hline & 18 July & 5 & 13 & 40 & 21 & 21 & 4230 \\
\hline & 29 August & - & 10 & 15 & 22 & 53 & 1940 \\
\hline \multirow[t]{3}{*}{ Festuca rubra, } & 22 May & 79 & 17 & 3 & 1 & 0 & 4360 \\
\hline & 18 July & 31 & 39 & 21 & 9 & 0 & 3260 \\
\hline & 29 August & - & 23 & 44 & 23 & 10 & 1420 \\
\hline
\end{tabular}


extend, compensate for reduced, early tiller growth. In both species 1000-seed weight appeared to be highest in latest sown crops (Table 2). This higher seed weight was attained although proportionally more panicles originated from later tiller generations, compared with the early sown crops. This result seems contradictory to published results on seed production of consecutive tiller generations in one crop. Often in crops the largest inflorescences and heaviest seed are produced by the tillers that emerge earliest (Anslow, 1964; Ryle, 1964; Langer \& Ryle, 1959). The higher 1000 -seed weight in the late-sown crops of the present experiments may be related to the lower numbers of seeds per panicle. Or maybe the large numbers of panicles in early-sown crops caused mutual shading, and reduced assimilate availability for seed filling.

\section{Inflorescence production in sowing rate experiments}

In grass seed crops it is often found that seed production is little affected by sowing rate. Fewer inflorescences and lower seed production will only occur when extremely low or high sowing rates are applied (Nordestgaard \& Larsen, 1974; Lampeter, 1972; Evans, 1963). Of greater importance was the study of how panicle production was achieved at different crop densities and why fewer panicles sometimes occur in dense crops. To this end, tillers were counted periodically and in the 1980 harvested experiment with smooth-stalked meadow grass all the newly emerged tillers were labelled every month, until January, by using a fixed grid. Data on the vegetative and reproductive growth of the crops are summarized in Table 5. The results of the labelling of the tillers are given in Tables 6 and 7 .

The difference in the sowing rate was eightfold. At the beginning of September at the higher sowing rate there were five times as many tillers in the smooth-stalked meadow grass crop and three times as many in the red fescue crop compared with the crops sown at the lower rate. During autumn these differences declined rapidly because tillering was hampered sooner in the denser sown crop. By December the differences in tiller density and tiller weight between crops were small. Nevertheless, in both species, and in both years significantly lower seed yields $(p<0.05$, Tukey) were recorded at the highest seed rates (Table 5). In these dense sowings there

Table 5. Effect of sowing rate on development and seed production of first year crops of Poa pratensis and Festuca rubra. Mean of two field experiments, harvested in 1979, 1981.

\begin{tabular}{|c|c|c|c|c|c|c|c|c|}
\hline \multirow[b]{2}{*}{ Sowing rate $(\mathrm{kg} / \mathrm{ha}) \rightarrow$} & \multicolumn{4}{|c|}{ Poa pratensis } & \multicolumn{4}{|c|}{ Festuca rubra } \\
\hline & 3 & 6 & 12 & 24 & 4 & 8 & 16 & 32 \\
\hline tillers $m^{-2}$, December & 3400 & 4050 & 4280 & 4670 & 7280 & 7870 & 8380 & 8410 \\
\hline tiller weight, $\mathrm{mg}$, December & 21 & 20 & 21 & 21 & 18 & 18 & 20 & 19 \\
\hline inflorescences $\mathrm{m}^{-2}$ & 3700 & 3780 & 3660 & 3170 & 3025 & 3045 & 2710 & 2365 \\
\hline seed yield, $\mathrm{kg} \mathrm{ha}^{-1}$ & 1658 & 1708 & 1696 & 1570 & 1311 & 1346 & 1319 & 1143 \\
\hline 1000 -seed weight, $\mathrm{g}$ & 0.36 & 0.36 & 0.36 & 0.36 & 0.96 & 0.95 & 0.96 & 0.95 \\
\hline mg seed per panicle* & 45 & 45 & 46 & 50 & 43 & 44 & 49 & 48 \\
\hline seeds per panicle* & 125 & 127 & 130 & 139 & 45 & 47 & 52 & 53 \\
\hline
\end{tabular}

${ }^{*}$ calculated. 
Table 6. Numbers and status at harvest (1981) of tillers from consecutive periods from sowing until the end of January. Poa pratensis sown at 3 and $24 \mathrm{~kg} \mathrm{ha}^{-1}$.

\begin{tabular}{|c|c|c|c|c|c|c|}
\hline $\begin{array}{l}\text { Sowing } \\
\text { rate }\end{array}$ & & $\begin{array}{l}\text { Sowing to } \\
\text { August }\end{array}$ & September & October & November & $\begin{array}{l}\text { Dec. and } \\
\text { Jan. }\end{array}$ \\
\hline \multirow[t]{4}{*}{$3 \mathrm{~kg} / \mathrm{ha}$} & emerged tillers $\mathrm{m}^{-2}$ & 1190 & 1500 & 970 & 1330 & 1000 \\
\hline & $\%$ reproductive & 81 & 81 & 66 & 50 & 30 \\
\hline & $\%$ vegetative & 0 & 1 & 2 & 6 & 12 \\
\hline & $\%$ dead & 18 & 18 & 32 & 44 & 58 \\
\hline \multirow[t]{4}{*}{$24 \mathrm{~kg} / \mathrm{ha}$} & emerged tillers $\mathrm{m}^{-2}$ & 2620 & 1750 & 1020 & 1420 & 1350 \\
\hline & $\%$ reproductive & 60 & 59 & 48 & 27 & 11 \\
\hline & $\%$ vegetative & 7 & 7 & 10 & 17 & 19 \\
\hline & $\%$ dead & 33 & 34 & 42 & 56 & 70 \\
\hline
\end{tabular}

also tended to be fewer panicles but differences were not significant.

In the densest crop of smooth-stalked meadow grass a considerably lower proportion of the tiller generations that were identified and labelled each month produced a panicle, and a higher percentage of the tillers died before harvest (Table 6). At both sowing rates it was found that the later the tiller generation appeared, the lower their capacity to produce panicles and the greater their mortality. Of the tillers that emerged during autumn and winter, only a few were vegetative and alive at harvest. This proportion of vegetative tillers was higher in the densely sown crop and increased in later appearing generations. The tendency for lower panicle production in the dense-sown crops can therefore mainly be attributed to the considerably higher mortality of tillers and also slightly to the greater proportion of tillers that remained vegetative. The latter phenomenon is noteworthy because it suggests that crop density has an effect on floral induction. Although the first labelled tiller generations had probably passed their juvenile stage and their low-temperature and short-day requirements could have been met, a greater proportion of tillers remained vegetative in the dense crop. It seems justifiable to infer that crop density affected tiller development before or during the inductive stage, because after attaining the double ridge stage of the apex, tillers can only flower or die.

Table 7. The contribution of tillers from different periods of emergence to the total no. of panicles and of vegetative tillers at harvest (1981). Poa pratensis sown at 3 and $24 \mathrm{~kg} \mathrm{ha}^{-1}$.

$\begin{array}{lllll}\begin{array}{l}\text { Sowing to } \\ \text { August }\end{array} & \text { September October November } & \begin{array}{l}\text { December } \\ \text { and Jan. }\end{array} & \begin{array}{l}\text { January to } \\ \text { harvest }\end{array} & \begin{array}{l}\text { Number of } \\ \text { tillers at } \\ \text { harvest }\end{array}\end{array}$

$\%$ of panicles

\begin{tabular}{|c|c|c|c|c|c|c|c|}
\hline & & & & & & & \\
\hline $3 \mathrm{~kg} / \mathrm{ha}$ & 24 & 30 & 16 & 16 & 8 & 7 & 4060 \\
\hline $24 \mathrm{~kg} / \mathrm{ha}$ & 43 & 28 & 13 & 10 & 4 & 2 & 3670 \\
\hline \multicolumn{8}{|c|}{$\%$ of vegetative tillers } \\
\hline $3 \mathrm{~kg} / \mathrm{ha}$ & 0 & 1 & 1 & 6 & 9 & 82 & 1260 \\
\hline $24 \mathrm{~kg} / \mathrm{ha}$ & 7 & 5 & 4 & 10 & 10 & 65 & 2540 \\
\hline
\end{tabular}


In the dense red fescue crops it was noticed that a few of the tillers died during winter. But in both species the highest mortality coincided with the period of stem elongation, as has been reported for other species (Hebbletwaite, 1977; Hill \& Watkin, 1975; Spiertz \& Ellen, 1972; Wilson, 1959). Ryle (1970) and Ong et al. (1978) demonstrated in ryegrass that the supply of assimilates to young, dependent tillers decreases abruptly at the onset of reproductive growth. From stem elongation onwards severe mutual shading also reduces the supply of assimilates to small tillers. These two processes together cause massive mortality of tillers, mainly of the smallest and latest emerged tillers.

In these smooth-stalked meadow grass and red fescue crops tiller mortality must also have been caused by these phenomena. But in the crops of these densely tillering species many older tillers died too. This shows that tillers that emerge early do not always have a competitive lead over tillers that emerge later. In these amenity grasses the growth of early tillers might be hampered by continuing tillering, and differences between younger and older tillers in size or weight might be less pronounced. In early spring, in a period of rapid tillering and the beginning of stem elongation, fierce competition for light and assimilates could occur between the many tillers of approximately equal size. In these vigorously tillering species it may even be more important to keep crop structure open during vegetative growth than in species with more robust tillers. In the densely sown red fescue crops, some vegetative stem elongation was also noticed before winter. The mortality rate of that tiller type is expected to be higher during winter (Minderhoud, 1980).

Several authors have studied management techniques aimed at reducing crop density. Drill spacing has often been found to have only minor effects on seed production, unless the spacing is extremely wide (Nordestgaard, 1979, 1977; Lambert, 1964, 1963; Evers, 1961). Removing parts of the grass rows ('gapping') has been found to give varying and inconclusive results (Canode \& Law, 1977; Lambert, 1964, 1963). Better results have been attained by post-harvest burning of stubble and straw residue in older stands (Chilcote et al., 1980; Canode, 1972). Similarly favourable results have been attained by closely clipping the stubble and removing all residue (Ensingn et al., 1983; Chilcote et al., 1980). In our trials tillers in the densest sown crops tended towards the elongated type described by Chilcote et al. (1980) in their unburned treatments, whereas the lowest sowing rates gave rise to the shorter and more prostrate tillers they reported in their burned plots. The latter authors suggested that competition for light was increased in crops of these inefficient elongated tillers, and that less young, active leaf tissue was present in these canopies. Kleinendorst (1969) has demonstrated that floral induction by low temperatures in perennial ryegrass has to be transferred via leaf tissue, independent of apex or root temperature. This may be why active leaf tissue is necessary. If this is so, the lack of active leaf tissue during autumn and winter could have impeded fertile tiller production in unburned fields (Chilcote et al., 1980) and in the densely sown crops in the experiments described in this paper. The density effect on tiller fertility before or during the inductive stage, as mentioned above, could be explained in this way.

In both field experiments on sowing rate, and also in each of the three sowing 
date experiments, seed yields per panicle in all treatments were similar and total seed yields depended greatly on panicle production. Several authors have reported the same close relationship between total production of inflorescences and seed yield (Langer, 1980; Nordestgaard, 1974; Stählin, 1972; Lewis, 1966). Hebblethwaite \& Hampton (1981) compiled data from experiments with perennial ryegrass over 10 years and concluded that there is a weak correlation between seed yield and ear numbers, but a close relationship between yield and seed numbers per area. From their research on perennial ryegrass Spiertz \& Ellen (1972) reported that in some of the treatments there was a high and positive correlation between ear numbers and seed yield, but in other treatments these yield components correlated negatively. The probable explanation for these conflicting findings is that yields of grass seed crops are mainly dependent on two components: the number of inflorescences per area, and floret utilization (i.e. the proportion of the florets that produces harvestable seed) (Lewis, 1966; Griffiths, 1965). The other two yield-determining factors (floret number and seed weight) seldom give rise to considerable variations in yield. Floret numbers depend greatly on the number of inflorescences and are affected similarly by most experimental treatments or crop management practices. Moreover, often less than one-third of the florets will produce a seed; this considerably reduces any potential differences. The remaining component is seed weight. In almost all published results of yield analysis, the variations in seed weight that result from treatments are much smaller than variations in numbers of inflorescences and floret utilization (Nordestgaard, 1980; Chilcote et al., 1980; Hebblethwaite \& Ivins, 1977). Langer \& Lamber (1963) related part of this limited variability of seed weight to probable losses of the lightest seed fractions at harvest. Given that the variations in floret numbers and seed weight are limited or dependent, the dominant influences of inflorescence number and floret utilization mean that seed yields almost always correlate strongly with their product: the number of seeds per area. A close correlation between inflorescence numbers and seed yield will be found in crops or treatments with approximately equal floret utilization, as can be expected for data on one variety and one year, or data from similar years. In data on many years and different varieties, or in experiments in which treatments affect floret utilization, only the numbers of seeds per area will correlate highly.

\section{Agricultural implications}

In the Netherlands stem elongation in smooth stalked meadow grass and red fescue seed crops begins at approximately the end of April and terminates the period of rapid spring tillering. Tillers that become reproductive later are at a great disadvantage for stem growth and realization of flowering. Assuming that in these grasses floral induction occurs at temperatures from $0-10{ }^{\circ} \mathrm{C}$, the period from November to April will be particularly suitable for vernalization (Fig. 3). Given that smoothstalked meadow grass requires 6-9 weeks (1000-1500 hours) of low temperatures and that red fescue requires low temperatures for 12-15 weeks (2000-2500 hours), and that the juvenile stage can be inferred from Fig. 1, then those tillers that are potentially able to produce inflorescences can be identified. At average temperatures and in open crops high fertility could be expected from smooth-stalked meadow 


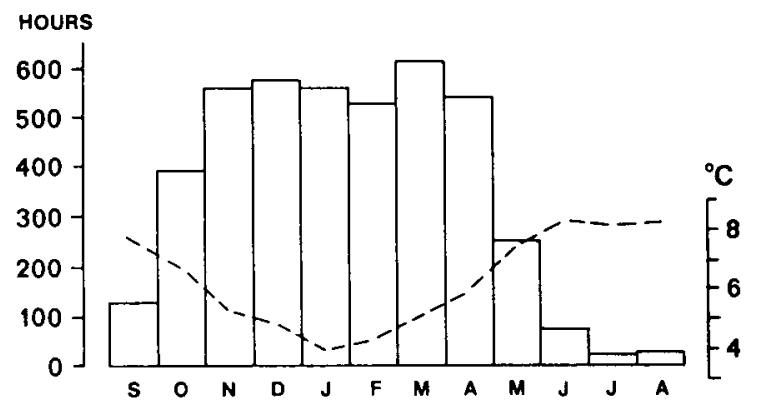

Fig. 3. The number of hours per month with temperatures between $0-10^{\circ} \mathrm{C}$ and the mean temperature (- - ) during these vernalizing hours. De Bilt, Netherlands, de Bilt, mean of 1971-1980.

grass tillers that emerge up to mid-January and from red fescue tillers that emerge up to mid-November. According to this calculation, the flowering ability of tillers that appear one or two months later should decline to almost zero. In other cultivars differences in inductive requirements and probably also in the duration of the juvenile stage will mean that developmental limits differ somewhat.

Labelling in the field crops revealed that younger and older tillers of red fescue produced fewer seed heads than when grown in pots: in contrast, in late-sown smooth-stalked meadow grass crops in the field, seed-head producing capacity of tillers was better than in the pot experiments (Table 3, Fig. 1). But in these latesown crops, to few tillers were produced for satisfactory panicle production. Early frost periods can also hamper tillering, and therefore it is concluded that in both species an adequate number of tillers should be attained before December. That fixed end of the vegetative growth period means that limits are also set to the sowing date. When these grasses are sown under a cover crop, the growth period can often only be prolonged by adaptations in cover crop management in order to improve growth conditions for the undersown grasses.

Often crops of low-tillering species or hay types with robust tillers develop as ideal seed crops: during vegetative growth a limited number of large tillers are formed and thereafter tillering decreases. In spring, at the onset of reproductive growth, crop density is high, but mainly because the tillers are leafy and not because tillers are numerous. In such crops the assimilate production per tiller will be high. Many densely tillering species and cultivars attain much higher tiller densities in their first year. Because of severe mutual shading and probably also because there are many dependent, young side tillers less assimilates are available per potential head-producing tiller. In such crops mortality of tillers could be high and fertility low.

In the field experiments described here, density effects were already apparent in these first-year crops (Tables 3 and 6). Often is tried to reduce crop density and to improve light penetration by gapping or by widening drill spacing, but without marked success. Probably the reduction of density in crops should occur more homogeneously and should last until well after the onset of the elongation stage. This could be achieved by reducing the numbers of tillers or by a reduction in the size of the leaves. Limiting the nitrogen fertilization would reduce tillering, but would also infere with the fertility of the tillers. Burning produces the desired effects on crop density: it removes crop residue and results in tillers with shorter leaves and shorter 
leaf sheaths (Chilcote et al., 1980). But free burning is not always possible and machine burning is expensive. Ensign et al. (1983) and Chilcote et al. (1980) have published evidence that very similar effects to burning can be achieved with close clipping and residue removal. In the Netherlands, vigorous first-year crops and older stands are often cut in autumn. In order to optimize crop structure and inflorescence production closer cuttings and the removal of residue would probably be beneficial.

\section{References}

Anslow, R. C., 1964 Seed formation in perennial ryegrass. Journal of the British Grassland Society 19(3) 349-357.

Bean. E. W., 1970. Short-day and low-temperature control of floral induction in Festuca. Annals of Botany 34: 57-66.

Bommer, D., 1961. Samen vernalization perennierender Gräserarten. Zeitschrift für Pflanzenzüchtung 46: $105-111$.

Bommer, D., 1967. Photoperiodic response and vernalization in grasses. Report of the Meeting. Fodder Crops Section, Eucarpia: 71-81.

Calder, D. M., 1966. Inflorescence induction and initiation in the Gramineae. In: F. L. Milthorpe \& J. D. Ivins (Eds.), The growth of grasses and cereals, pp. 59-73 Butterworths, London.

Canode, C. L., 1972. Grass seed production as influenced by cultivation, gapping and postharvest residue management. Agronomy Journal 64 (2): 148-151.

Canode, C. L., \& M. Perkins, 1977. Floral induction and initiation in Kentucky bluegrass cultivars. Crop Science 17 (2): 278-282.

Canode, C. L.. \& A. G. Law, 1977. Post-harvest residue management in Kentucky bluegrass seed production. Bulletin 850, Agricultural Research Center, Washington State University.

Chilcote, D. O., H. W. Youngberg, P. C. Stanwood \& S. Kim, 1980. Post-harvest residue burning effects on perennial grass development and seed yield. In: P. D. Hebblethwaite (Ed.), Seed production, pp. 91-103. Butterworths, London.

Clemence, T. G. A., 1982. Seed production by amenity ryegrass Lolium perenne. $\mathrm{Ph}$. D. thesis, University of Nottingham.

Colvill, K. E., \& C. Marshall, 1981. The patterns of growth, assimilation of 14-CO2 and distribution of 14-C-assimilate within vegetative plants of Lolium perenne at low and high density. Annals of Applied Biology 99: 179-190.

Cooper, J. P., \& D. M. Calder, 1964. The inductive requirements for flowering of some temperate grasses. Journal of the British Grassland Society. 19: 6-14.

Elliot, C. R., 1966. Floral induction and initiation in three perennial grasses. Dissertation Abstracts. 27 (6) 1686-B.

Ensign, R. D., V. G. Hickey \& M. D. Bernardo, 1983. Seed yield of Kentucky bluegrass as affected by post-harvest residue removal. Agronomy Journal 75: 549-551.

Evans, L. T., 1960. The influence of temperature on flowering in species of Lolium and in Poa pratensis. Journal of Agricultural Science, Cambridge 54: 410-416.

Evans, G., 1963. Seed rates of grasses for seed production. Empire Journal of Experimental Agriculture 31 (121) 34-40.

Evers, A., 1961. Graszaadteeltproeven 7. Mededelingen PAW 49: 1-59.

Fejer, S. O., 1960. Ear emergence in perennial ryegrass as affected by differences in light and temperature before ear initiation. New Zealand Journal of Agricultural Research 3: 558-564.

Foster, C. A., 1969. The influence of planting date on the seed-bearing capacity of tillers of perennial ryegrass spaced plants grown for seed. Journal of the British Grassland Society 24: 271-276.

Griffiths, D. J.. 1965. Breeding for higher seed yields from herbage varieties. Journal of the National Institute for Agricultural Botany. 10: 320-331.

Hebblethwaite:P. D., 1977. Irrigation and nitrogen studies in S. 23 ryegrass sown for seed. Journal of Agricultural Science, Cambridge 88: 605-614. 
Hebblethwaite, P. D. \& J. D. Ivins, 1977. Nitrogen studies in Lolium perenne grown for seed. Journal of the Britisch Grassland Society 32: 195-204.

Hebblethwaite, P. D. \& J. G. Hampton, 1981. Physiological aspects of seed production in perennial ryegras. Report of the Meeting, Fodder Crops Section, Eucarpia: 17-32.

Heide, O. M., 1980. Studies on flowering in Poa pratensis L. ecotypes and cultivars. Scientific Reports Agricultural University Norway 59 (14): 1-27.

Hill, M. J. \& B. R. Watkin, 1975. Seed production studies on perennial ryegrass, timothy and prairie grass. Journal of the British Grassland Society 30: 63-71.

Kleinendorst, A. \& R. Brouwer, 1965. The effect of temperature on two different clones of perennial ryegrass. Mededelingen IBS 282: 29-39.

Kleinendorst, A., 1969. The effect of low temperature around shoot, growing point and root on the vernalization of Lolium perenne. Mededelingen IBS 40: 11-18.

Kleinendorst, A., 1974. Some effects of vernalization on the reproductive capacity of Lolium perenne $\mathrm{L}$. Netherlands Journal of Agricultural Science 22: 6-21.

Lambert, D. A., 1963. The influence of density and nitrogen in seed production stands of S37 cocksfoot (Dactylis glomerata L.). Journal of Agricultural Science, Cambridge 61: 361-373.

Lambert, D. A. 1964. The influence of density and nitrogen in seed production stands of $\$ 48$ timothy (Phleum pratenseL.) and S215 meadow fescue (Festuca pratensis L.). Journal of Agricultural Science, Cambridge 63: 35-42.

Lambert, D. A. \& O. R. Jewis, 1970. The position in the plant and the date of origin of tillers which produce inflorescences. Journal of the British Grassland Society 25 (1) 107-112.

Lampeter, W., 1966. Gelöste und ungelöste Probleme in der Erzeugung von Grassaatgut. Grünlandsymposium Leipzig: 1-15.

Langer, R. H. M. \& D. A. Lambert, 1959. Ear bearing capacity of tillers arising at different times in herbage grasses grown for seed. Journal of the British Grassland Society 14: 137-140.

Langer, R. H. M. \& D. A. Lambert, 1963. The physiological significance of population density in grass seed production. Journal of the British Grassland Society 177-180.

Langer, R. H. M., 1980. Growth of the grassplant in relation to seed production. In: J. A. Lancashire, (Ed.), Herbage seed production, pp. 6-11. New Zealand Grassland Association.

Langer, R. H. M. \& G. J. A. Ryle, 1959. The effect of time of sowing on flowering and fertile tiller production in S48 timothy. Journal of Agricultural Science, Cambridge 53: 145-150.

Lewis, J., 1966. The relationship between seed yield and associated characters in meadow fescue. (Festuca pratensis). Journal of Agricultural Science, Cambridge 67: 243-248.

Lindsey, K. E. \& M. L. Peterson, 1964. Floral induction and development in Poa pratensis L. Crop Science 4: $540-544$.

Minderhoud, J. W., 1980. Triebformen bei Lolium perenne L. Rasen 2: 35-41.

Murray, J. J., A. C. Wilton \& J. B. Powell, 1973. Floral induction and development in Festuca rubra L. Crop Science 13: 645-648.

Nordestgaard, A. \& A. Larsen, 1974. Seed growing experiments in frames with cocksfoot, meadow fescue and smooth meadow grass. Tidsskrift for Planteavl 78: 116-130.

Nordestgaard, A.. 1977. Seed rates of perennial ryegrass for seed production. Tidsskrift for Planteavl 81: 351-324.

Nordestgaard, A., 1979. Seed rates of Cocksfoot for seed production. Tidsskrift for Planteavl 83: 111122 .

Nordestgaard, A., 1980. The effects of quantity of nitrogen, date of application and the influence of autumn treatment on the seed yield of grasses. In: P. D. Hebblethwaite, (Ed.), Seed production, pp. 105-119. Buttersworth, London.

Ong., C. K., 1978. The physiology of tiller death in grasses. 1. The influence of tiller age, size and position. Journal of the British Grassland Society 33: 197-203.

Ong, C. K., C. Marshall \& G. R. Sagar, 1978. The physiology of tiller death in grasses 2 . Causes of tiller death in a grass sward. Journal of the British Grassland Society 33: 205-211.

Robson, M. J., 1968. The changing tiller population of spaced plants of S170 tall fescue (Festuca arundinacea). Journal of Applied Ecology 5: 575-590.

Ryle, G. J. A., 1964. The influence of date of origin of the shoot and level of nitrogen on ear size in three perennial grasses. Annals of Applied Biology 53: 311-323. 
Ryle, G. J. A., 1967. Effect of shading on inflorescence size and development in temperate perennial grasses. Annals of Applied Biology 59: 297-308.

Ryle, G. J. A., 1970. Distribution patterns of assimilated 14-C in vegetative and reproductive shoots of Lolium perenne and L. temulentum. Annals of Applied Biology 66: 155-167.

Stählin, A., H. Geidel \& G. Bogdan, 1972. Zum Problem der Dünnsaat bei der Saatguterzeugung von Futterpflanzen. Zeitschrift für Acker- und Pflanzenbau 135: 226-246.

Spiertz, J. H. J. \& J. Ellen, 1972. The effect of light intensity on some morphological and physiological aspects of the crop perennial ryegrass (Lolium perenne $\mathrm{L}$. var. Cropper) and its effect on seed production. Netherlands Journal of Agricultural Science 20: 232-246.

Wilson, J. R., 1959. The influence of time of tiller origin and nitrogen level on the floral initiation and ear emergence of four pasture grasses. New Zealand Journal of Agricultural Research 2: 915-932. 